\title{
SOME ENGINEERING ASPECTS OF RIVER BASIN DEVELOPMENT
}

\author{
Arno T. Lenz
}

Engineers are concerned with river basin development in two ways: First, they and their associates in meteorology, geology, and soil science are responsible for the collection of the physical data which tell how much water there is in the basin under consideration and how that water is distributed. Secondly, when these facts are known or can be estimated with reasonable accuracy, engineers must plan, design, build, and operate structures to control the water for the benefit of man. This article will briefly explore the nature and scope of these engineering roles.

I

\section{HYDRoLOGY}

\section{A. The Hydrologic Cycle}

The central concept of hydrology is the hydrologic cycle. This describes the circulation of water from its vapor form in the atmosphere, through precipitation, largely as rain or snow, its disposition by infiltration into the ground or by surface runoff into rivers, its storage in lakes and seas, and its eventual return, through evaporation and transpiration, to the atmosphere. The cycle is exceedingly complex and variable. There are short-cuts and delays: some raindrops are evaporated as they fall and complete the cycle in a few moments; other water molecules lie for ages in dead storage as glacial ice or in the deep seas. The cycle continues perpetually because heat energy from the sun, through evaporation and transpiration, lifts water to the atmosphere, and gravity pulls it back down to earth, over the earth's surface and within the geologic strata.

\section{B. Basic Data}

The water available for river flow is primarily dependent on precipitation. This varies greatly, geographically and with respect to time, seasonally as well as over longer periods. There are cycles in precipitation, but they are so complex as to be of little value for predicting the future. Looking backward at what has happened at a particular location during a specific period is somewhat more rewarding. The most regular variation is the seasonal one which occurs within each year, but even here, precipitation during extremely wet or dry periods fluctuates widely from the average value.

* B.S. 1928, M.S. 1930, C.E. 1937, Ph.D. 1940, University of Wisconsin. Professor of Hydraulic Engineering and Director of the Hydraulic Laboratory, University of Wisconsin; consulting hydraulic enginecr. Author of various papers on hydrology and hydraulics. 
Precipitation is measured and studied by meteorologists, climatologists, and hy: drologists. In the United States, it is the responsibility of the Weather Bureau, United States Department of Commerce, to record precipitation data and publish them. Daily precipitation amounts and the monthly totals are published in Climatological Data for hundreds of gages all over the United States and its territories. Generally, publication is by states and for calendar months. The thirteenth publication each year is an annual summary which contains monthly totals for each gage and also the annual total for the calendar year. Rainfall amounts for individual hours are published in Hourly Precipitation Data for selected stations which have recording gages. These data are necessary when studying rainfall of high intensity for short duration.

Various other governmental agencies at the federal and sometimes the local level also collect records. Power companies, irrigation districts, and some individual farmers and ranchers may also have records of value. Many of these, however, are collected in cooperation with the Weather Bureau and published in the regular manner.

Rain which falls on the ground either infiltrates into the soil or runs off into the streams and lakes. Initial infiltration is usually at a higher rate than the average, especially after long dry spells. These rates are greatly influenced by the type and condition of surface soil and sometimes by the subsoil, particularly when the surface soil is thin. Surface detention by contour furrows and dense vegetal cover, such as heavy grass growths and forest leaf mould, all retard surface runoff, at least temporarily, and tend to increase infiltration, other things being equal. The slope of the ground surface is also an important factor in determining the speed of runoff and, therefore, the opportunity for infiltration.

Surface runoff into the streams, lakes, and rivers is the residue from rainfall after the infiltration capacity of the soil has been satisfied. The surface runoff is added to the base flow of the streams, and the total runs off the land into the seas if it is not evaporated along the way. The base flow comes from the ground water, which is replenished by infiltration. During dry periods, the rate of ground-water flow into the streams decreases, and there is gradual recession of the base flow. In semiarid regions, where there is little ground water, the streams dry up completely between rains.

In northern regions and at.high altitudes, winter precipitation is largely in the form of snow, which may be stored for several months before it runs off in the spring and early summer. Snow surveys are made in the western mountains and a few other places to determine the water content of the snow pack. Thus, in streams fed by extensive fields of melting snow, it is possible to determine, with a relatively high degree of accuracy, the relation of each year's snowmelt runoff to the mean for several years and to estimate its effect on water supplies.

In the United States, it is the responsibility of the Geological Survey, United States Department of the Interior, to measure streamflow and publish these data in 
DISCHARGE HYDROGRAPHS WISCONSIN RIVER BASIN
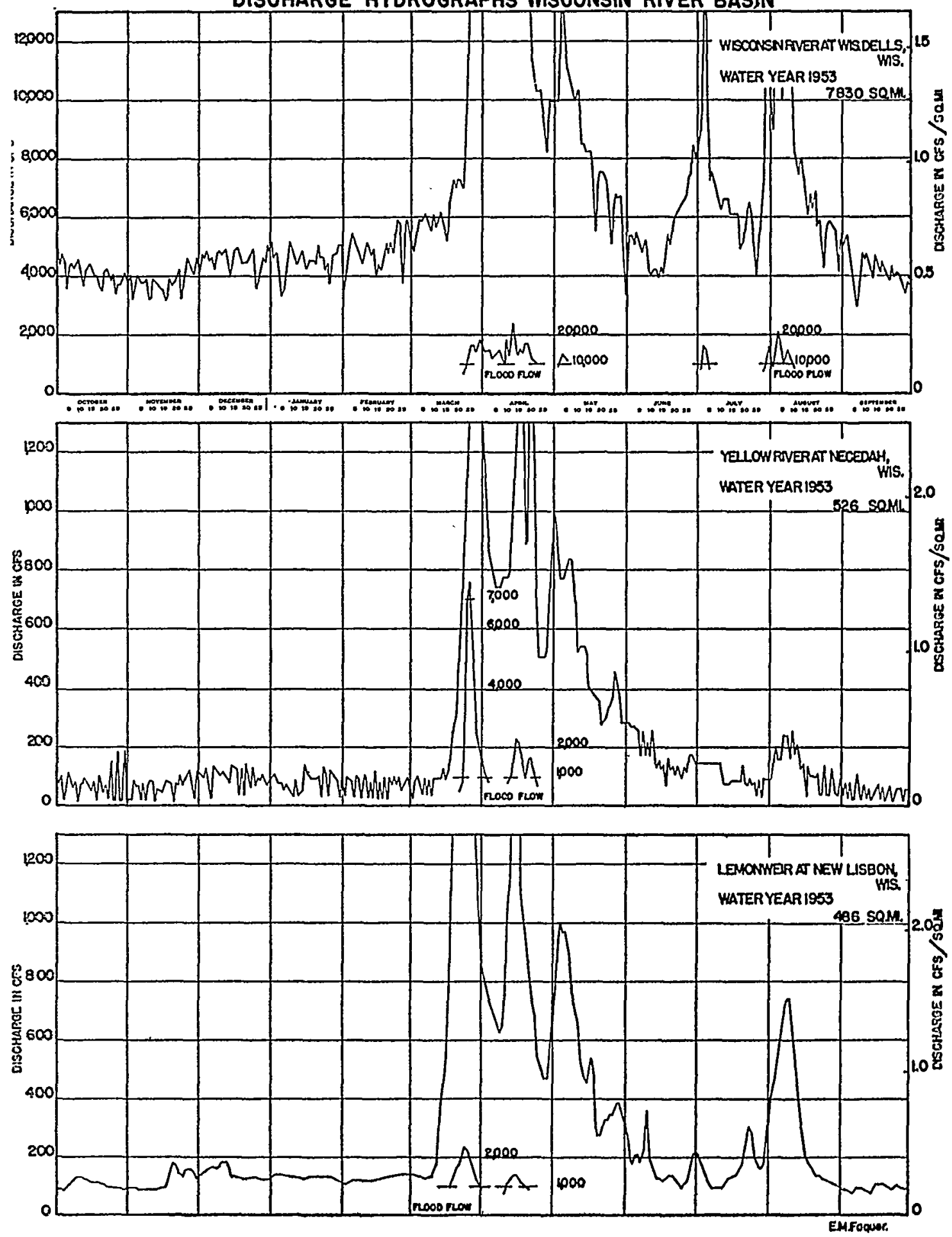

FIGURE I 
Geological Survey Water-Supply Papers. The records are collected for fourteen river basins, some of which are further divided into parts $A$, $B$, etc. For each gage, the average daily flow in cubic feet per second is given for each day of a "Water Year," beginning October $\mathrm{r}$ of a year and ending on the next succeeding September 30. The $195^{6}$ Water Year, for example, is defined as that ending September 30, 1956. The Water-Supply Papers contain data as to the gage location; the drainage area in square miles which contributes water to the river at the measuring point; gage description; the average and extremes of discharge for the entire record, for the year, and for each month, and remarks regarding the quality of record; and upstream regulation and diversion.

It should be noted that the "years" used by the Weather Bureau and Geological Survey do not embrace the same twelve-month period. It is a simple matter, of course, however, to compute the average precipitation for a "water year" or the average streamflow for a "calendar year," if necessary.

\section{Streamflow Analysis}

Streamflow data can best be visualized by plotting daily flows in chronological order for a year in a curve known as a "discharge hydrograph" (some examples of which are set forth in Figure $\mathrm{I}$ ). The selection of scales is important, because at times, it is desirable to show detailed variations in flood flows; at others, variations in base flows. Sometimes, more than one scale is used, one being ten or even 100 times another; even logarithmic scales are used.

When such records are plotted for several years, certain patterns become obvious, such as the beginning of snowfelt runoff in the north; the slow rise to a late spring or early summer peak and rather slow recession to base flow which is characteristic of streams draining high mountain areas; the effect of Sunday reductions in power plant loads, which, during a month, cause four or five reductions in flow at seven-day intervals; the effect of major reservoir storage, which may reduce flows to nearly zero during periods when other rivers are in flood. These graphical patterns and others tell stories to trained hydrologists and hydraulic engineers. It would be much more difficult to visualize this same information from tabulated data.

When the same data for a year are arranged in order of magnitude, such a curve is called a "discharge duration curve" (some examples of which are set forth in Figure 2). When curves for several years are compared, it is a simple matter to select the years with the generally highest and lowest flows' and also a year which represents average conditions.

Geographic, annual, and seasonal variations in streamflow become evident when curves for various rivers and years are compared. There are, of course, many detailed methods of analysis to supplement these, but discharge hydrographs and duration curves tell much that becomes obvious to judge and jury, or boards of directors, or legislators. The results they show can be understood by those not specially trained in hydrology, but they can best be interpreted by trained hydologists. These curves are essential to intelligent river basin planning and engineering control. 


\section{DISCHARGE DURATION CURVES}

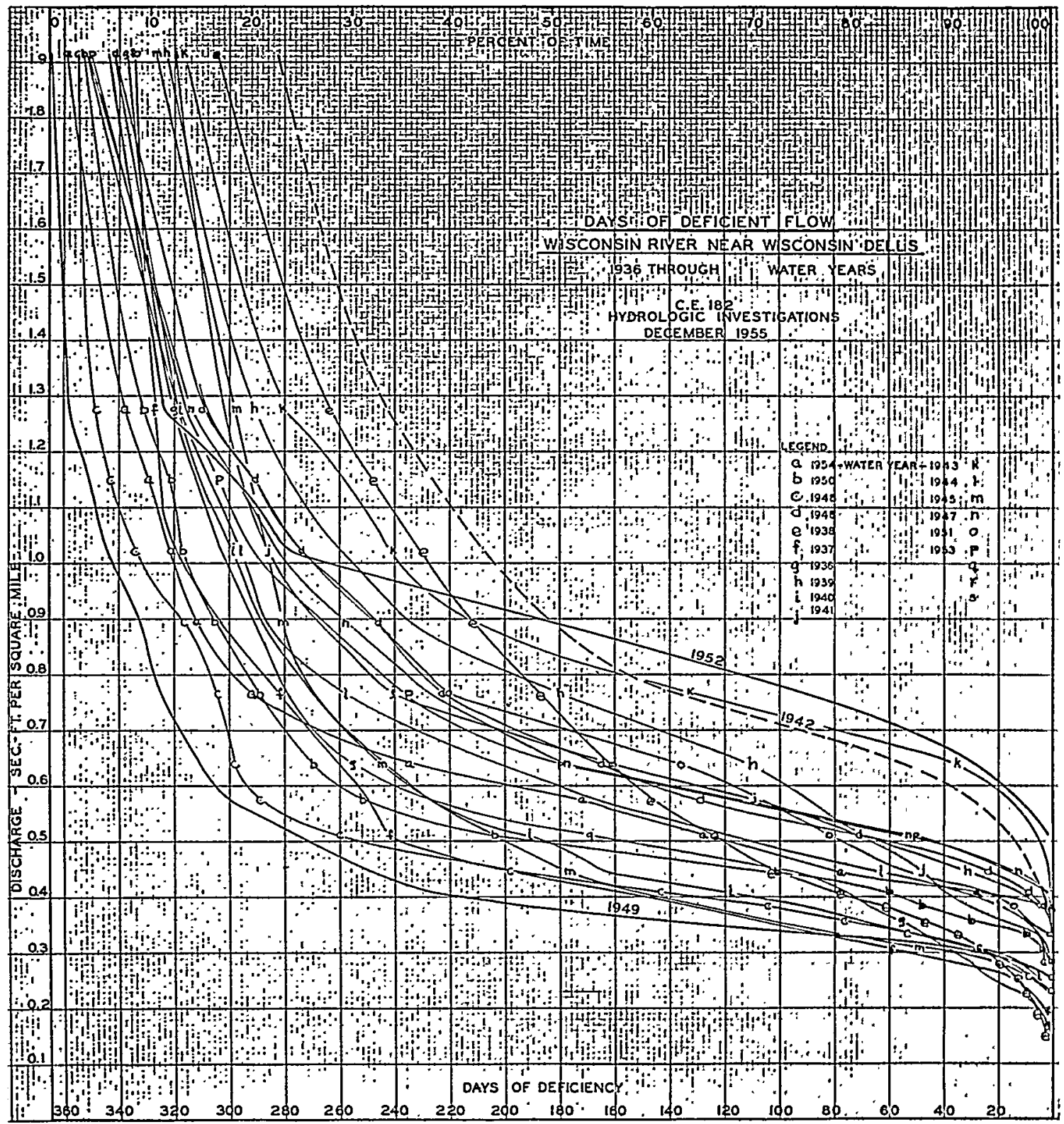

FIGURE 2 


\section{ENGINEERING CONTROL}

\section{A. Natural Control}

Engineering control of rivers must supplement natural control if development is to be most effective. Natural control depends on such things as the shape of the basin, the stream pattern, storm paths, and storm patterns, as well as other physical characteristics of the soils, geology, etc.

The shape of the basin may be nearly circular, as is true for the Rock River basin above Afton, Wisconsin, or it may be long and narrow, like the Connecticut River basin. In the first case, flood waters from the boundary all get to the outlet at nearly the same time, independently of storm paths. In the second, the flood characteristics are much dependent on whether the storm moves upstream or downstream.

The stream pattern within the basin is also of importance. At one extreme, we have the Jefferson, Madison, and Gallatin Rivers, each draining its own relatively wide basin and converging at Three Forks to form the Missouri River. At the opposite extreme, the Clinch and the Powell Rivers drain long narrow valleys between the ridges in east Tennessee and join just upstream from Norris Dam. These latter rivers are in valleys with short steep slopes which quickly dump their water into the main rivers and create flood peaks which move at rates which can be calculated quite accurately-as TVA engineers did calculate them during the construction of Norris Dam.

When a river flows northeast in the eastern United States, as does the Genésee River in New York, melting snow and ice from the headwaters can pile up on a frozen river downstream and be aggravated by rain which falls first on the headwaters. Flash floods result. Fortunately, in the great upper Mississippi and Ohio River basins, most storms fall first on the outlets of the river basins, and the local runoff from these areas may be dissipated before rain on the headwaters enters the rivers. The direction of storm movements also has an obvious influence on this same problem. Where storms move in different directions across or along a basin, the flood peaks ay have quite different magnitudes.

\section{B. Methods of Engineering Control}

Various man-made techniques, such as dams, levees, drainage, irrigation, and soil conservation, all have been used for water control. They may be used singly or in combination, and often a technique may be used in different locations to accomplish different purposes.

Dams are used to store water in river valleys, but if the water level behind the dam is held constant, the dead storage, once filled, has little effect on streamflow. Yet, this operation provides the maximum head for water power production. Moreover, it is only when the water is drawn out of the reservoir behind the dam that it becomes useful for irrigation and flood control. Only when the reservoir is full, however, does it provide the maximum potential for irrigation, and only when it is empty 
does it provide the maximum potential for flood control. Thus, reservoirs are subjected to many conflicting operating demands.

Levees are used to confine flood waters and prevent them from spreading over flat lands adjacent to river channels. By confining the water, levees tend to raise the river level and this may be beneficial for navigation. Yet, confining a river all along its channel raises the flood level and the required levees to heights greater than would necessarily be the case if only occasional levees were constructed.

Drainage depresses the groundwater level and thereby helps render low land more suitable for agricultural and other purposes. Waters are discharged rather slowly, so there is little effect on rates of river flow, except when drainage waters flow into small creeks with little or no natural flow. The land itself, however, is greatly affected by drainage.

Irrigation, of course, greatly affects the land to which the water is applied, and the withdrawal of irrigation water from a river can significantly affect streamflow rates, because where irrigation is practiced, water in rivers is usually scarce and any depletion is noticeable. The storage of flood waters is usually quite necessary for dependable and successful irrigation from surface runoff.

Soil conservation by means of contour plowing, strip cropping, and the planting of soil and water-holding crops is of value in retaining the water as well as topsoil on the land. It is difficult, however, to measure the benefits in terms of inches of water or dollars per acre.

\section{Problems of Water Use and Supply}

\section{r. Domestic and Industrial Water Supply}

Although a man only drinks about five pints of water a day, his other uses of water in the community in which he lives increase the average demand on municipal water supplies to I50 gallons per capita per day, of which total residential, commercial, and industrial demands each account for a third. In the West, where lawn-sprinkling is a necessity, many communities must supply even higher requirements.

East of the hundredth meridian, municipal demands for water are ordinarily met with relative ease, except in a few instances, such as New York and Philadelphia, for example, where demands are very large, water collecting systems are elaborate, and water must be transported long distances between source and distribution. Most of the large cities in the East and Midwest are on the Great Lakes or on large rivers, and water supplies are adequate. Chicago, Cleveland, Detroit, Milwaukee, Cincinnati, and St. Louis, to name just a few, have adequate supplies, and their water demands for municipal uses other than waste disposal have little effect on other uses of water in the river basins.

In the West, however, conditions are quite different. In the dry areas, large cities must, of necessity, go greater or lesser distances to insure a suitable water supply, and even smaller communities have water supply problems much greater 
than those experienced by communities of similar size in the East. Los Angeles, from the first, had its problems and is now supplied in part from the Colorado River, through the great Los Angeles Aqueduct, by waters stored behind Hoover Dam. In this region, water demands for domestic supplies have profound effect on other uses for water.

Ground water supplies many communities with an adequate source of pure cold water at low cost. Such sources, however, are sometimes endangered by contamination from wastes of the municipality itself, industries, or even farms or ranches. And increased use of ground water for air conditioning can lower the water table to such an extent that pumping costs may increase to several times the original cost and may even reduce the supply available for normal usage. Return of water from airconditioning systems may also warm the ground water to such an extent that it becomes useless for that and other purposes. Ground water supplies, accordingly, must be protected for the most important uses in any river basin plan.

Industrial demands for water are also great and must be supplied if our present civilization is to continue. About roo,000 gallons of water are used in the manufacture of each automobile, and $77^{\circ}$ gallons are required for each barrel of oil used by that automobile. From 60,000 to 85,000 gallons are used to produce each ton of wood pulp used in the manufacture of a morning paper. Almost all manufacturing processes, in fact, demand water.

These water demands may be for consumptive or nonconsumptive use. Water used for power turbines in hydroelectric generating plants is unaffected in quantity or quality, so this is perhaps the highest of all nonconsumptive uses. Water used to condense steam in a large power station is not used consumptively, nor is its quality impaired, but its temperature is raised. Various uses could be described, and as one goes down the list, it would be evident that appreciable amounts of water are actually combined with the product, as in the canning of foodstuffs, for example, and necessary consumptive uses result. Yet, even in a cannery, much of the water is used for sanitary protection of the product and is returned to the hydrologic cycle in nearly the original quantity, but contaminated by wastes.

Water quality, then, is also important in water-use planning. Quality may depend on either bacterial or mineral content, and water may be unsuitable as a supply for either or both reasons. Domestic water supplies must be free of bacterial contamination, but the mineral content may be fairly high. Thus, many groundwater supplies, despite a high calcium content, are used for domestic purposes. These same waters, however, are entirely unsuitable for boiler feed water without softening. On the other hand, completely soft water with moderate bacterial contamination would be suitable for boilers, but unsafe for human consumption. Data on the mineral content of river waters is published in certain of the Geological Survey Water-Supply Papers.

\section{Stream Pollution}

Water is also used to dispose of our domestic and industrial wastes. In the early days, simple dilution of the relatively small amount of wastes to be disposed of was 
sufficient. The oxygen demand was so slight that the dissolved oxygen content of the streams was not lowered to levels dangerous for fish life, and the waters never became offensive. Later, however, these oxygen demands became so great that in some instances, all the oxygen in a stream was used and it became a flowing cesspool. But recently, by the use of primary and secondary treatment of wastes, it has become possible materially to reduce the oxygen demand of the effluent of treatment plants to such amounts that the oxygen depletion of streams is held within safe limits. The oxygen demand is expressed as B.O.D. (Biochemical Oxygen Demand), in units of ppm. (parts or pounds (of demand) per million pounds (of water)). If more million pounds of water are available for dilution, the oxygen demand can be satisfied more easily. Therefore, the minimum streamflow rate is of greatest importance, particularly at times of greatest rates of waste disposal. Dry-weather streamflow can be augmented by water storage, so planning for this use of a river is of great importance.

\section{Navigation}

Adequate depth must be provided at all points in the navigation channel of every river and canal used for shipping. This depth can be obtained by dredging the channel bottom, or it can be obtained by raising the water surface. During flood periods, the water level is high, and rivers such as the Ohio can be navigated without the use of navigation aids to raise the water level. During low-flow periods, however, low dams are used to raise the water level over shoal areas. The river profile then becomes a series of steps, and boats must be passed through locks to get from one slack water-pool level to another.

This type of navigation improvement has little effect on other water uses in a river basin. The water level in the river is maintained at or above a minimum level. As the flow increases to flood conditions, gates control the water behind the dams so that the levels change slowly and are generally held to maximum elevations not greatly different from those which would occur if no dam existed. The dams, therefore, exert little or no influence on flow rates or maximum flood elevations. They do maintain minimum elevations, however, and this benefits pumping plant intakes which draw water from above a dam.

When barge tows must go through many locks with small lifts, the time required can add appreciably to the cost of transport. Modern design calls for the replacement of a series of small dams and locks with one which provides a single lift of equal magnitude. Somewhat greater land areas are flooded, but otherwise there is little difference in operations.

Levees also can be used to raise the surface level of a river by confining the flow to a narrow channel. And cutting off bends can make shorter navigation channels and provide deep regular canals to replace shallow meanders. These navigation aids can help in flood protection, too, if properly designed for both purposes.

Elimination of low flows in rivers is another method of raising the water surface. With given channel conditions in the shoal areas, engineers can determine what 
minimum flow is required to provide the necessary navigation depth. If the natural river flow is insufficient, the rate can be increased by the release of water from storage reservoirs, such as Fort Peck on the Missouri, for example. From estimates of the lowest natural flow to be expected and the durations of the drought and navigation seasons, it is possible to compute the volume of storage needed. This may be provided in one or more reservoirs on the main river or its tributaries. Certain complications arise because of the time required for storage releases to get to the point required, however, and forecasting of flows and river stages is an important feature of such operations.

Storage water released to aid navigation is obviously of no use for irrigation purposes, unless the irrigation withdrawal is downstream from the critical reach for navigation. Releases for navigation which maintain flows above a certain minimum are helpful in the abatement of stream pollution, however, providing the greatest waste concentration is not added at times outside the navigation and flood seasons. Reservoirs designed to provide water for navigation only may also be helpful in the control of floods, but they will be of little help if the flood comes when the reservoir is full at the beginning of a navigation season. Maintaining a minimum flow greater than the natural minimum without water storage is very helpful in hydroelectric generation, too, because it increases the firm power capabilities of plants all the way down the main stem of such rivers as the Tennessee or Columbia, for example. If the navigation season is only in the summer, however, and the minimum flows are not maintained during the winter when power demands are greatest, there will be no true increases in firm power production.

\section{Flood Control}

Traditionally, man has protected himself from rising flood waters by erecting a wall or levee to keep the water from his home and property. Along the lower Mississippi River and in many other places, this method has been used successfully. Originally, the first protection was provided for the property of highest value, and ring levees around cities or those which surrounded cities on the river side and tied into high banks on the land side proved quite effective. These levees constricted the river channel in their vicinity, however, and created a control section which raised the flood-water level by an amount proportional to the amount of constriction.

In time, it was inevitable that levees would be extended up and downstream until the river was entirely confined. Oversimplifying complex hydraulic interrelations, two things may be said to have resulted: (I) for a given flood, the river level was raised between levees, because with the river width restricted, the depth had to be increased to accommodate the same volume of water; and (2) the flood volume moving down the channel was increased, because water which previously had been temporarily stored on the flooded river banks had to run down the channel between the levees. As levee systems grew, therefore, the levee heights were raised; and when foundation conditions permitted and sufficient money was available to build 
levees to the height necessary, they were used to protect areas against floods of even the greatest magnitude.

Economic considerations, however, often dictate that certain other plans be used to augment a levee system. One way is to provide auxiliary floodways parallel to the main river as secondary channels to divert some of the water during the heaviest floods. Where physical conditions permit, these channels are closed off by gates, as at Bonnet Carré on the Mississippi River above New Orleans, or by fuse plug levees, which are overtopped and wash out when the river reaches a certain height. Agricultural areas within the floodways may be used to yield crops during most years, but they are subject to occasional flooding which is necessary to protect other lands which presumably are of greater value.

Flood-control reservoirs to store part of the water volume and release it after the flood peak has passed have also proved effective when physical conditions permit. For example, the Miami Conservancy District in southwestern Ohio has a series of dams, each of which is built with a fixed opening, like a culvert pipe, through which the river ordinarily flows. The opening is of such size that it limits the flow to the capacity of the river channel downstream. When a flood occurs and the flow exceeds the outlet capacity, the excess volume is stored behind the dam and gradually fills the reservoir until inflow becomes less than the outlet capacity and the reservoir drains. These reservoirs are large enough to accommodate a flood forty per cent greater than the great I913 flood, which took more than 300 lives and caused damage exceeding \$roo,000,000. Emergency spillways will pass even greater floods and protect the structures, but flows will then exceed the river channel capacities. Lands in the reservoir areas are used for agricultural purposes when not covered by flood waters.

Most flood-control reservoirs are constructed with gates and depend on control by man to govern their operation. The wider such control can be extended, the greater the benefit that can be effected; but such control is subject to the limitations in man's knowledge and the influence of pressure groups. By combining the use of reservoirs for flood control with use for power, irrigation, and other purposes, a substantial part of the cost can be repaid out of earnings. Such multiple-purpose operation, however, will be discussed later.

"Upstream engineering," by the construction of farm ponds and erosion-control struitures and the adoption of agricultural practices such as contour plowing, strip cropping, and terracing, are useful for their primary purpose of providing an agricultural water supply and holding valuable top soil on the land where it is needed. When an attempt is made to evaluate this work in terms of basin-wide planning, however, one encounters arguments pro and con which are beyond the scope of this discussion.

\section{Water Power}

The power available from a river is directly proportional to the flow through the turbines and the head which is acting on the turbines. If the power is expressed 
in horsepower, it is just slightly less than one tenth the product of the flow $(Q)$ expressed in cubic feet per second and the head $(H)$ expressed in feet. Expressed in kilowatts $(K W)$, the power is about one-fourteenth $Q \times H$.

It becomes evident, therefore, why engineers seek in every possible way to increase the head available at a water-power plant and to hold the upstream water level at the highest level at all times. When stored water is drained from above the power dam, the water level falls. When the head is reduced to one-half the original amount, the power output of the plant is reduced to one-half the original amount, even though the same volume of water is used with both heads. For maximum power production, it is essential that there be no reduction in the headwater level, except possibly when small amounts of stored water are withdrawn immediately prior to spring floods which can be predicted with certainty.

Within the limits of the plant capacity, a single-purpose water-power plant uses the flow of a river as it comes to the plant, and flow regulation is rather limited. If, however, the upstream pool or pond (reservoir) has large size relative to the demand rate, it is possible to regulate the power output and, consequently, the river flow downstream from the plant over a period of one week, without any great effect on the headwater level and the power output. Then, ponded water is slowly used in excess of inflow for the working days of a week and replaced on Sunday and possibly Saturday, when water use is less than inflow. This use of pondage, of course, has no effect on seasonal streamflow variations or those of greater magnitude during extended droughts.

When large storage reservoirs are built to catch flood waters and release them gradually during dry periods and are designed to be drained completely, it is seldom economical to install power units at the dam because of the low head and power output available for a major portion of the time. On the other hand, if the outlet at the dam can be discharged into a pipeline or tunnel and additional fall developed by building the power house at a lower elevation downstream or even in a different watershed, it may be very economical to combine a storage reservoir and power plant. Moreover, storage reservoirs which increase the dry-weather river flows benefit all water-power plants downstream; and when they are operated by private or quasipublic agencies, as in the Wisconsin and Chippewa River basins in the state of Wisconsin, toll charges are made in proportion to the benefits received by each water user.

Water releases for power can help navigation, aid in the control of the stream pollution, and provide water for domestic and industrial uses, because power plants require water throughout the year. They can be helpful for irrigation also, but it must be remembered that when a consumptive use, such as irrigation and some domestic and industrial uses, removes water from a river, that water is no longer available for water-power plants downstream from the point of use. A possible exception is that of return flow of irrigation water which results from seepage from canals and water applications in excess of vegetative use. Irrigation return flows 
are delayed in transit, however, and may or may not return when they are of benefit to the water-power plants.

Water releases for power must be replaced during flood periods, and the water so stored reduces the amount of flood waters which flow downstream. This reduction in volume often reduces the peak rate of flood flow also; but this is not necessarily so, because the reservoir, if it is small, may become filled with the first part of a flood and have no effect when the peak flow passes down river.

\section{Irrigation}

Both surface flows and groundwater are used for irrigation. The simplest method is to divert a river to a canal which falls very slowly as compared to the original river channel and, at some distance below the point of diversion, apply the water to lands which lie below the canal and above the river. No pumping is required, because flow is by gravity. When small amounts of water are taken from large rivers, the physical problem is simple, although the legal one may be quite complex.

Streamflow characteristics are important when more than the minimum river flow is to be diverted, and storage reservoirs must be used if any major part of the annual water yield is to be diverted for irrigation. In much of the United States, the irrigation season is limited to the summer and early fall, so that water releases primarily for irrigation are not of great value for water power unless supplemented by additional water releases for power, navigation, and other purposes.

Other consumptive uses of water are in direct competition with irrigation and generally are not compatible, although they may be coordinated, particularly if they do not occur at the same time.

\section{Drainage}

Drainage projects are greatly influenced by other water uses, because an area to be drained of excess water must first be protected from flood waters contributed by outside areas. Then, a system of open ditches or tile drains must be installed to remove the water which remains. Finally, an outlet for the excess water must be found. If this outlet can discharge by gravity into an adequate creek or river, it is possible to eliminate the pumping plant which would otherwise be necessary and save the cost of pumps and the power required to run them.

The effect of drainage projects on other water uses is of lesser importance and is frequently beneficial rather than destructive. Drainage provides a place where falling rain can be stored to prevent immediate runoff. Water is discharged from a drainage project rather slowly, over a long period of time, and frequently at a fixed rate determined by pumping capacity or the design of certain control works. Thus, a drainage project may act to retain excess water in exactly the same manner as certain flood-control projects are designed to act.

Drainage may also provide streamflow additions at times when they are needed for pollution control, water-power production, or irrigation needs. These additions, however, may not be of the quality necessary for irrigation water. This is particu- 
larly true when drainage is from alkali soils and results from over irrigation of desert regions.

\section{Soil Conservation}

Engineering methods of water control for soil conservation are primarily limited to the construction of erosion-control dams and the construction of terraces. Contour plowing has much the same effect, but this can hardly be called an engineering method.

An erosion-control dam consists of a concrete or stone spillway structure by means of which water is conducted from a higher to a lower level without destructive erosion on the way down. The spillway is supplemented by an earth-fill dam where necessary to confine the flow of water and concentrate it. These dams are built across deep gullies or at their heads to prevent them from eating back upstream each time high flows concentrate at the earth drop-off point. In badly eroded regions, hundreds of such structures are necessary to stop this type of erosion. However, sheet erosion of the top soil will continue independently of the gully erosion unless some cover crop is planted to hold the soil in place.

In plowed fields on moderate and steep slopes, terraces are often constructed along the contour to break up long slopes, from hilltop to valley, into a series of shorter sections. Each of these is short enough so that water flowing down the slope does not attain erosive velocities. The terraces, therefore, reduce the amount of sheet erosion. Water collecting in the terrace flows along it perpendicular to the slope, until it reaches a terrace outlet which permits the water again to flow down the slope in specially protected, nonerodable channels of sod or concrete.

These conservation methods hold back moderate amounts of water and tend thereby to increase infiltration. Their influence on other water problems is less than is sometimes supposed, because their water-holding capacity is limited and proportionally more effective on the smaller floods.

\section{Multiple-Purpose Projects}

In recent years, when large dams and storage reservoirs began to be constructed, when water resources began to be regarded as increasingly important, and when increased construction costs made it necessary to secure support from many sources, multipurpose projects became popular. In essence, they may be said to be quite effective and economical in satisfying several water uses, but they are not as effective as a series of single-purpose projects could be at much greater cost.

Let us take as an example a high dam with a large reservoir designed for flood control, water power, navigation, domestic and industrial water supply, stream sanitation, and irrigation. Let us assume that the greatest flood danger occurs in December and January, the maximum power demand occurs in December, the navigation season extends from April through October, water-supply demands are uniform through the year, malaria control demands occur in summer, and irrigation demands increase from June $I$ to the end of July and decrease to nothing by the end of 
September. Theoretically, the reservoir operations might follow a pattern like this:

The water level would never be permitted to rise above the elevation of the spillway crest, except when such a rise were necessary to pass flood waters. Gates fifteen feet high would control these floods and could hold the water that much higher throughout the year. The five per cent this would add to the annual power output if the crest were 300 feet above the river downstream would be charged to floodcontrol costs. In addition, by January $\mathrm{r}$, the water level would be drawn down forty feet more to accommodate the expected January floods.

During January, the reservoir would be filled by the expected floods, and the water stored would reduce or eliminate flood damage downstream. If necessary, part of the top fifteen feet of the reservoir capacity would be used to store these flood waters, but that part would be emptied as quickly as possible after the flood danger had passed in order to maintain that storage as a reserve for emergencies which cannot be predicted.

In the period February through May, the worst flood threat would be assumed to be over, and so the water would be held at crest level and the power units would operate at design capacity. There would be no demand from storage for navigation, irrigation, or malaria control. This would generally be a high-flow period, and power would benefit most from reservoir control which would permit the carrying of peak demands much in excess of natural streamflow, if the water were replaced at times of low power demand.

Beginning in June, or earlier if natural streamflow were deficient because of low rainfall, navigation and irrigation demands would necessitate releases of storage water. The required releases might be the sum of the two demands or somewhat less than that amount, depending on the location of irrigation diversions, tributary inflow locations and rates, critical navigation problem reaches, and similar factors. These releases would lower the headwater level behind the dam and thereby reduce the power output. On the other hand, these same releases would be passed through the turbines and would produce extra power during these months because of the extra flow available, although the power operators would prefer to have this extra power in December, at the time of peak power demands. Because of the malariacontrol demands that have been assumed, the rate of release would be greater than average for five or six days each week and less than average for one or two days. The reservoir level would then be fluctuated up and down to prevent the formation of stagnant pools in which mosquitoes might breed. This is most important when reservoir level fluctuations are small. Irrigation demands would be over by the end of September, but navigation demands might continue until the end of October or November in northern regions and throughout the year in the South.

If the various demands had removed enough stored water to make room for expected December floods, no further reduction in reservoir level would be necessary. Otherwise, further releases might be necessary in November to reduce the headwater level to the required elevation. 
In December, the reservoir would be down to the lowest level when power operators would like it at the highest level. With the hydrologic and operating conditions assumed, however, floods in December might provide excess flow which would offset, to some extent, the deficient head. This would require excess generating capacity, which would add to the capital cost.

Domestic and industrial water-supply demands would have major or minor influence on the above operating schedule, depending on their magnitudes and variability. Small uniform demands would have little influence; large demands create the primary purpose for regulation.

Multipurpose operation of a single reservoir, thus, is obviously not simple, but it should be noted that the control of water at dozens of dams, as in the TVA system, for example, is extremely complicated. Some of the reservoirs in the tributaries, Norris, Fontana, Hiwassee, and others, are multipurpose. Others, also on the tributaries, Nantahala, Blue Ridge, Calderwood, for example, are better operated as singlepurpose reservoirs which are coordinated with the multipurpose reservoirs. Finally, the main river dams from Knoxville to the Ohio River are operated to maintain navigation levels, produce power, and assist in flood control. The control of such a system is dependent on "rule curves," which show the probable minimum water level for any date in the year, the normal operating level, the maximum multipurpose level, and probable maximum level under extreme flood conditions. Operating within these limits, engineers decide when to drain, when to fill, when to carry power load at one dam or another, and many other associated problems.

\section{III}

\section{CoNCLUSION}

The engineer's roles in river basin development are thus seen to be pervasive and long-continuing ones-extending from the conduct of hydrologic surveys to the planning, construction, and operation of water-control works. Valuable as these contributions may be, however, the ultimate success of a river basin development program will primarily be determined by the manner in which and the ends to which these ancillary services are employed.

\section{SELECTED BIBLIOGRAPHY}

Arthur E. Carhart, Water-Or Your Life (r95I).

E. A. Colman, Vegetatión and Watershed Management (1953).

Conservation Foundation and the National Association of Manufacturers, Water in Industry-A Survey of Water Use in 3000 Plants (1950).

Bernard Frank and Clifford A. Betts, Water and Our Forests (195I).

W. G. Hoyt and W. B. Langbein, Floods (T955).

Luna B. Leopold and Thomas Maddock, Jr., The Flood Control Controversy (I954). Harold E. Thomas, The Conservation of Ground Water (I95I).

United States Department of Agriculture, Climate and Man: The Yearbook of AgriCOLTURE (X94I). 
United States Department of Agriculture, Water: The Yearbook of Agriculturi (1955).

United States Forest Service, Department of Agriculture, Know Your Watzrshed (Leaflet No. 282, 1948).

United States Public Health Service, Water Pollution in the United States (USPHS Pub. No. 64, 1951).

Water Resource Jevelopment (I953) (excellent map of U. S. water-resource development, flood-control, and irrigation activities of the Department of Army, Corps of Engineers, Department of Interior, and TVA).

Bello, How Are We Fixed for Water? Fortune, March 1954, p. 120.

Nichols and Colton, Water for the World's Growing Needs, National Geographic, Aug. x952, p. 269.

Plenty of Water-But None to Waste, Business Week, Sept. 9, 1950, p. 82.

Smith, Our Water Supply-Vital Economic Factor, The Magazine of Wall Street and Business Analyst, Nov. 1955, p. 180.

U. S. Water -We Can Supplement Our Outgrown Resources-At a Price, Life, Aug. 2r, r950, p. 47.

Water-A Special Report, Power, Sept. 1950, p. 72. 